\title{
ENCONTROS EDUCATIVOS ENTRE A DANÇA, O ENSINO DA DANÇA E PAULO FREIRE
}

\section{EDUCATIONAL CONNECTIONS BETWEEN DANCE, DANCE EDUCATION AND PAULO FREIRE}

\author{
Camila Moura Cardilo - UEMG \\ Cirlene Cristina de Sousa - UEMG
}

\section{RESUMO}

$\mathrm{O}$ artigo tem como objetivo identificar possíveis encontros entre a dança, o ensino de dança e a educação humanizadora freireana. Além da leitura de artigos e trabalhos acadêmicos sobre dança, debruçou-se sobre as pedagogias de Paulo Freire. A partir desta pesquisa bibliográfica, notou-se alguns pontos de convergência entre a dança, no seu princípio educativo, e a educação freireana, no seu sentido libertador. A partir dessa convergência, chegou-se a cinco encontros fundamentais entre a dança, o ensino da dança e a educação humanizadora freireana, a saber: dança - movimento, dança - emancipação; dança - corpo molhado de cultura; dança - comunicação e dança - conscientização. Na conclusão, destaca-se a dança como um exercício libertador complexo do ser humano no mundo. O dançar não se pode resumir a uma tarefa mecânica do corpo. Ao contrário, a dança é uma atitude humana, um fazer-se, um colocar-se como corpo em movimento, como corpo consciente de si e do mundo.

Palavras-chave: Dança. Ensino da dança. Educação humanizadora. Paulo Freire.

\begin{abstract}
The article aims at identifying possible encounters between dance, dance education and Freire's humanizing education. In addition to reading articles and academic works about dance, the pedagogies of Paulo Freire were examined. Based on this bibliographic research some points of convergence between dance, in its educational principle, and Freire's education, in its liberating sense, were noted. From this convergence five fundamental encounters were reached between dance, dance education and Freire's humanizing education, namely: dance - movement, dance emancipation, dance - body wet with culture, dance - communication and dance consciousness. In conclusion, dance is highlighted as a complex liberating exercise of the human being in the world. Dancing cannot be reduced to a mechanical task of
\end{abstract}


the body. On the contrary, dance is a human attitude, a doing of oneself, a putting oneself as a body in movement, as a body conscious of itself and of the world.

Key-words: Dance. Dance Teaching. Humanizing Education. Paulo Freire.

\section{Introdução}

A dança tem uma relação fecunda com a vida humana. Ela é um ato, uma ação, uma atitude de comunicar e vincular a experiência de um corpo consciente, biográfico, sensível, social e cultural num determinado contexto. Ao dançar, homens e mulheres se conectam consigo mesmos e com o mundo. Assim, nossas corporeidades estão atravessadas por memórias e experiências que envolve cada ser com sua própria história. Neste artigo, debate-se a dança no seu sentido educativo humanizador e libertador. Para tanto, fez-se um estudo de artigos científicos sobre a relação dança e educação e a educação humanizadora em Paulo Freire. O objetivo central foi analisar possíveis conexões entre a dança, no seu sentido educativo, e a educação freireana, no seu sentido libertador, como destacaremos nas páginas que se seguem.

\section{Dança no seu princípio educativo humanizador}

Sabemos que, desde os tempos mais remotos, os seres humanos já praticavam rituais que envolviam a dança e o movimento do corpo. Neste percurso, a dança permanece nas sociedades, porque faz parte do ser, do sentir de homens e mulheres. Ela ocupa diversos lugares sociais e pode ser uma crença, um costume, um momento de lazer, um trabalho artístico, uma peça denunciativa e ou um elemento do currículo escolar. Ao longo dessa trajetória, a dança foi se tornando danças e, muitas vezes, refletindo o que acontecia no mundo e com as pessoas. Danças, ditas no plural, porque ao se colocar como uma experiência do humano, a dança faz notar a própria diversidade posta em nossa humanidade. Dançamos porque somos seres históricos, dançamos porque a história dos nossos corpos são campos de possibilidades de nos aprendermos mais humanos.

Da dança clássica à dança contemporânea, o ser humano vem produzido modos de se comunicar com e no mundo. Segundo Vianna (2005), sem desconsiderar toda a beleza que a dança clássica carrega, ela hoje não atende à necessidade que o corpo humano diverso tem de se expressar, de se comunicar. Se num sentido mais clássico, o corpo tende a ficar mais preso em movimentos moldados, mecanizados. Ao longo da história, os seres humanos vão apresentando necessidades de novas posturas corporais e de novas formas de se comunicarem. Via tais necessidades, outras maneiras de dançar vão sendo aí reveladas, trabalhadas, ensinadas e aprendidas.

E neste processo, o corpo humano vai ganhando mais liberdade em seus movimentos. Novas manifestações, novos conceitos, novas denúncias e anúncios sobre o nosso ser e estar no mundo vão surgindo e, a dança, tem aí um papel importante. Da dança clássica a contemporânea, por exemplo, foi se observando que 
homens e mulheres, ao dançar, vão se conscientizando do seu estar no mundo. Esta dimensão da conscientização tem uma relação direta com a perspectiva educativa de Paulo Freire (1987) pois, para este autor, a prática educativa é aquela que desperta no sujeito uma conscientização de si e do mundo que o cerca; que permite troca de saberes; que motiva os sujeitos, nela envolvidos, a busca contínua de conhecimento; que os liberta de práticas excludentes e estáticas.

Nesse sentido, o corpo é um lugar fundante das nossas experiências mundanas. Por meio dele, produzimos sentidos e significações, sentimos prazeres e dores, vivemos amores e desamores, anunciamos afetividades e denunciamos opressões. Portanto, o corpo nos serve como bússola que indica direções, caminhos que nos fazem experienciar contornos e contextos diversos sobre o nosso ser no mundo. Como diria Paulo Freire (2020), o mundo é nosso palco e nele os pormenores da vida vão se tornando saberes, "saberes de experiência feitos 1 " e tantos outros. Vida que para este educador é práxis livre e emancipada. Nesse mesmo sentido, Jorge Larrosa (2020) destaca que se

a experiência é o que nos acontece e se o saber da experiência tem a ver com a elaboração do sentido e do sem-sentido do que nos acontece, trata-se de um saber finito, ligado à existência de um indivíduo ou de uma comunidade humana particular; ou de um modo ainda mais explícito, trata-se de um saber que revela ao homem concreto e singular, entendido individual ou coletivamente, o sentido ou o sem-sentido de sua própria existência, de sua própria finitude. Por isso, o saber da experiência é um saber particular, subjetivo, relativo, contingente, pessoal. Se a experiência não é o que acontece, mas o que nos acontece, duas pessoas, ainda que enfrentem o mesmo acontecimento, não fazem a mesma experiência. $O$ saber da experiência é um saber que não pode separar-se do indivíduo concreto em quem encarna. Não está como o conhecimento científico, fora de nós, mas somente tem sentido no modo como configura uma personalidade, um caráter, uma sensibilidade ou, em definitivo, uma forma humana singular de estar no mundo [...]. (p.32)

John Dewey (2010, p.70) contribui para esse debate ao destacar que a experiência "ocorre continuamente, porque a interação do ser vivo com as condições ambientais está envolvida no próprio processo de viver" (DEWEY, 2010, p.109). O ambiente é o local onde a vida se desenrola - "não apenas nele, mas por causa dele" (Idem, p.74). Assim, a experiência tem uma relação íntima com a história e com a memória de cada ser humano. O corpo que se permite experienciar é um corpo que se entrega ao tempo e nele vive trocas, diálogos, contradições, reflexões e movimentos. Quando dançamos, permitimos que os corpos se conectam, se percebam e percebam o outro.

Assim, a dança, enquanto movimento que acontece no espaço, no tempo e, principalmente, no corpo, exige de nós atitudes de criação, de recriação, de invenção, e, por isso, é sempre uma experiência formativa e política. Ela é, portanto, indispensável à concretude dos processos de socialização entre os seres humanos.

1 "Uma coisa continua em mim o respeito intenso à experiência e à identidade cultural dos educandos. E um grande respeito, também, pelo saber "só de experiência feito", como diz Camões, que é exatamente o saber do senso comum" (FREIRE, 2020, p.290). 
Neste sentido, a dança, no seu princípio educativo, é capaz de nos fazer experienciar as aventuras e dialéticas de nossa humanização, por isso ela nos educa.

O primeiro autor a falar sobre a dança educativa foi Rudolf Laban², na década de 1910. Ele descreveu o movimento como uma obra construída no espaço que forma desenhos por meio dos ritmos traçados pelo corpo e, assim, mesmo que não tenha um som, é possível identificar a intensidade com que o corpo dança (LOPES, 2008)3 e nesta intensidade o corpo na, com e em dança vai desempenhando o seu papel na vocação humana de ser mais 4 e, assim, se humanizando.

Em 2018, no II Congresso internacional Paulo Freire: o legado global, na Universidade Federal de Minas Gerais (UFMG), foi apresentado um trabalho, intitulado: A dança e a cultura sob um "olhar" de Paulo Freire (GOMES et al., 2018) que teve como objetivo fazer uma pequena reflexão sobre Freire, a dança e seus contextos culturais. O autor abriu uma discussão a respeito das colocações do encontro das perspectivas freireanas com a dança e o ensino da dança em suas dimensões educativas. Principalmente, em contextos em que homens e mulheres vivenciam ações opressoras e desumanizadoras. Gomes (2018) defende, ser fundamental, um ensino de dança emancipador, ensino de um corpo consciente do seu lugar no mundo. Assim, enquanto uma prática educativa, o ensino da dança deve se comprometer com o processo de conscientização, de autonomia e de libertação dos seres humanos. Nesse sentido, "a dança é a ação e ação dialógica de denúncia de uma realidade opressora e anúncio de sua libertação pelas suas práxis (GOMES et al, 2018, p.6).

Para Gomes (2015), a educação precisa estimular a visão crítica e formar sujeitos para a emancipação, autonomia e humanização. No entanto, é preciso cuidado quando o ensino se faz mediante técnicas ou práticas corporais, podendo esse, seguir um percurso contrário a educação emancipadora (ADORNO, 1995 apud GOMES, 2015). Para Gomes, o ensino de dança somente estimula a formação humana se oferecer caminhos para a subjetividade; possibilidades de autocrítica, autorreflexão e autonomia. O autor nos lembra ainda que para Paulo Freire qualquer ensino que dê "algo dado", concreto e definido bloqueia qualquer possibilidade de construção e interesse pela aprendizagem. Por isso, as experiências com e em dança como processo formativo precisam tocar, provocar e interagir os que estão aí envolvidos.

Em sua perspectiva processual, a dança não pode ser notada apenas como reprodução de coreografias, mas compreendida como uma situação formativa do ser, em seu desenvolvimento individual, coletivo e em sua formação humana. Essa perspectiva processual busca reafirmar o significado do corpo sensível e reivindicar o seu lugar imprescindível no campo do saber:

2 Foi bailarino, autor de várias coreografias famosas, renovador da dança e de seu enfoque teatral [...] dirigiu seu trabalho principalmente para a dança, como meio de educação". (VECCHI, 1978, p. 9).

3 O método Laban chegou no Brasil através de Maria Duschenes, em 1940. Ela propôs uma conexão entre processo de ensino-aprendizagem nas escolas às ações terapêuticas (NAVAS; DIAS, 1992 apud MARQUES 2011). Duschenes, trouxe-nos ainda a primeira reflexão a respeito da dicotomia entre arte e educação ao destacar que as escolas não devem formar artistas mas sim sujeitos livres, criativos e expressivos.

$4 \quad$ "A categoria "ser mais encontra-se situada na obra de Freire como um conceito, chave para sua concepção de ser humano. Como tal, articula-se com outros conceitos definidores da visão antropológica, sóciopolítica e história de Freire, tais como: "inédito viável", "inacabamento" e "possibilidade histórica". Na Obra pedagogia do oprimido, Freire concebe "ser mais" como desafio da libertação dos oprimidos como busca da humanização”. (ZIRKOSKI,2016a, p.369-370). 
por meio de suas cicatrizes culturais, sociais, políticas, estéticas, filosóficas e científicas, o corpo reflete a pertença a um determinado tempo-espaço. Olhar para o corpo, é olhar para a sociedade ao qual ele pertence [...]. O corpo torna-se condição para a existência do sujeito, constituindo sua própria humanidade. (CAMAZZOLA, 2017, p. 16)

Diante desta perspectiva da dança educativa, o dançar pode movimentar ideias, culturas, construir e (des)construir saberes. O dançar é uma oportunidade para homens e mulheres se aprenderem humano, se aprenderem inconclusos, portanto, educáveis. E é nesta experiência da educabilidade humana, que enfrentamentos opressões e ou produzimos libertações. É nesta compreensão da libertação que a dança se encontra com a educação humanizadora freireana. Debate que se inscreve no eixo a seguir.

\section{Encontros possíveis entre a dança e a educação humanizadora freireana}

Como notado ao longo desse artigo, a dança enquanto prática educativa, forma nossas corporeidades para um estar crítico, dialógico e participativo no mundo. E é nesta experiência de estar sendo no e com o mundo que se faz perceptível a dança como um campo importante para a nossa humanização. Humanização que, para Paulo Freire, é uma aprendizagem conectada ao sentido de práxis libertadora, aquela que nos educa para ser no mundo. Ou seja, eu "[...] não estou no mundo, eu sou no mundo[...]" (FREIRE, 2005, p. 53).

Para alguns estudiosos, a dança como uma forma de conhecimento pode ser vinculada a esta dimensão freireana da práxis libertadora, já que enquanto conhecimento, ela envolve o ser que dança em "toda sua plenitude, sensibilidade e racionalidade [...] na dança o corpo é o próprio conhecimento que é desvelado nas experiências sentidas, imaginadas e vividas. (BARRETO, 2004, p. 127). Portanto, ela possibilita que nos aprendamos humanos, seres criadores e transformadores das realidades. Seres com historicidade, portanto, programados para aprender, como diria Paulo Freire.

Nas páginas que se seguem, pontuamos o encontro entre a dança, o ensino da dança e a educação humana freireana, elencando cinco dimensões educativas, a saber: dança-movimento; dança-emancipação; dança-corpo molhado de cultura; dança-comunicação; e, por fim, dança-conscientização.

\section{Dança - movimento}

Para Paulo Freire "uma educação crítica, radical, não pode jamais prescindir da percepção lúcida da mudança que inclusive revela a presença interveniente do ser humano no mundo" (FREIRE, 2016, p.34). Nesse sentido, todo ato de educar deveria estar comprometido com este debate da nossa presença no mundo. Presença que para Paulo Freire implica "escolha e decisão, não seja uma presença neutra" (p.35). A mudança é um processo que se pode notar no campo dos costumes, do gosto estético de modo geral, das artes plásticas, da música, popular ou não, no campo da moral, sobretudo no da sexualidade, no da linguagem e das corporeidades. 
Para estudiosos da dança, o corpo que dança tem uma relação direta com este compromisso de mudar ou de pensar o mundo. Pois, o ato de dançar é comunicação, arte, cultura e movimento que sempre estiveram associados à natureza humana e à sua corporeidade (GARIBA; FRANZONI, 2007). São os movimentos que levam o corpo à comunicação em suas diversas maneiras; utiliza-se deles e dos sentidos como mediadores de todo fluxo de informações entre o ser humano e o mundo. $\mathrm{Na}$ infância, por exemplo, as experiências motoras constituem a base para a construção de um método corporal motor e cognitivo das relações, criando símbolos que são refletidos durante toda a vida do indivíduo (NOGUEIRA, 2008). No dizer de Barreto,

[...] sou antes de tudo o que faço, enquanto danço sou dança, se agora escrevo, sou o próprio ato da escrita, a palavra, o gesto. Entretanto, interpretar o fenômeno mencionado é também criar uma dança que possibilite a expressão de pensamentos e dizeres de outros. É permitir que nesta dança em mim se percebam outras formas, sentidos, vozes, que as danças se encontrem revelando o entrelaçamento de olhares... (2004, p. 6667)

Portanto, o movimento associado a consciência corporal, nos permite mudar. É a partir dessas transformações que o sujeito descobre caminhos para solucionar problemas e mudar a realidade. Movimentar também é se libertar de prisões que não nos deixam evoluir. Para Paulo Freire, o inacabamento do nosso ser é que provoca as mudanças contínuas na existência humana do qual também necessitamos para viver. É nesta perspectiva da mudança, que Paulo Freire coloca a sua docência, assim ele diz:

como professor crítico, sou um "aventureiro" responsável predisposto a mudança, à aceitação do diferente. Nada do que experimentei em minha atividade docente deve necessariamente repetir-se. Repito, como inevitável, a franquia de mim mesmo, radical, diante dos outros e do mundo. Minha franquia entre os outros e o mundo mesmo e a maneira radical como me experimento enquanto ser cultural, histórico, inacabado e consciente do inacabamento. [...] Na verdade o inacabamento do ser, ou sua inconclusão, é próprio da experiência vital. Onde há vida, há inacabamento. Mas só entre mulheres e homens o inacabamento se tornou consciente. (FREIRE, 2018, p. 49-50)

Percebe-se, a partir da citação acima, uma intensa ligação da palavra inacabamento com a palavra movimento, no sentido de que o conhecimento não é estático, mas sim, mutável. Como seres incompletos, necessitamos desse movimento para conhecer e (re)construir saberes. Assim, o movimento representa impacto, não como algo que aconteceu ou que vai acontecer, mas que está acontecendo.

Eden Silva Peretta (2019), no artigo Presença e inacabamento: aproximações entre dança e o pensamento crítico de Paulo Freire, notou zonas de interação entre essas dimensões centrais sobre o movimento no pensamento de Freire e alguns procedimentos contemporâneos de criação em dança. $\mathrm{O}$ pesquisador revisita as obras freireanas e coloca a importância do corpo ser resistência perante as questões sociais e históricas. Notou-se que a dança, como movimento do corpo numa determinada realidade, é um processo de educação do nosso ser no mundo, um ato 
que proporciona uma conexão, criação e transformação desta realidade, como se observa no fragmento abaixo:

[...] quando a dança encontra a educação, além das possíveis abordagens psicológicas, estéticas, poéticas, terapêuticas ou motoras, traz consigo um forte potencial crítico e formativo, dando origem a formas sutis de contestação e resistência social [...] problematizar essa realidade em busca de outras formas de sentir-se corpo, apresenta-se como um interessante horizonte educacional, um objetivo pedagógico que poderia sugerir métodos modestos, mas concretos, de resistência cultural. (PERETTA, 2019, p.378)

Ainda para Peretta (2019) a dança, enquanto movimento corporal, é um processo de desconstrução de ideias, pois, o pensamento também é corpo. Quando movimentamos ideias, movemos também a curiosidade, o interesse pela experimentação e pela criação. Assim, o movimento corporal é a ação pela qual materializamos as mudanças e expressamos nossas percepções do mundo. Com o corpo, podemos contar histórias, desenhar objetos, manifestar desejos e sentimentos. O movimento é algo infinito e inacabado. A partir de um movimento inicial, podemos criar inúmeros outros movimentos. A dança, assim, não deve ser uma experiência de padronização, e, sim, de recriação, de experimentação do nosso agir no mundo.

É deste debate da nossa ação no mundo, que se faz a partir da produção de movimentos que nos educam, que os estudiosos da dança se aproximam da reflexão freireana sobre educação e mudança, educação e movimento.

Na obra Pedagogia da Indignação, por exemplo, Paulo Freire (2016) destaca que a educação deve ser sempre uma prática crítica e radical do nosso saber-se no mundo. Nesse sentido, se a minha presença no mundo, na história não é neutra, é preciso que eu assuma

tão criticamente quanto possível sua politicidade. Se na verdade, não estou no mundo para simplesmente a ele me adaptar, mas para transformá-lo; se não é possível mudá-lo sem um certo sonho ou projeto de mundo, devo usar toda possibilidade que tenha para não apenas falar de minha utopia, mas para participar de práticas com ela coerentes. (FREIRE, 2016, p.36)

É neste sentido de uma prática coerente e transformadora, que a dança se torna um processo educativo humanizador. Uma experiência educativa que não castra a altivez dos nelas envolvidos e se coloca como prática de consciência biófila, aquela que se coloca em busca das coisas vivas e luta contra aqueles e aquelas que tem amor às coisas mortas. Estas dimensões da consciência biófila e/ou necrófila são dois conceitos que Paulo Freire (2016) toma emprestado do alemão Eric Fromm. Para este autor uma pessoa de consciência necrófila:

é impelida pelo desejo de transformar o orgânico em inorgânico, de aproximar-se da vida mecanicamente, como se todas as pessoas vivas fossem coisas. Todos os processos, sentimentos e pensamentos vivos são transformados em coisas. Memória em vez de experiência; ter, em vez de 
ser, é o que interessa. O necrófilo pode relacionar-se com um objeto - uma flor ou uma pessoa - somente se possuir esta (p. 43-44)

Ao contrário, aqueles e aquelas de consciência biófila tem sempre a perspectiva de se movimentar em direção às coisas vivas. Ou seja, a consciência biófila é a experiência de amor à vida e o que nela estão vivos. Por isto, o ato de dançar biófilo nos emancipa. Emancipação no seu sentido freireano, como notaremos a seguir

\section{Dança - emancipação}

Na obra Pedagogia do Oprimido, Paulo Freire nos convoca a pensar sobre a pedagogia que existe na luta dos que são feitos esfarrapados de suas humanidades, de suas corporeidades, mas que não se aceitam passivamente nesta situação. Os oprimidos e oprimidas, apesar de viverem condições de desumanizações, estão sempre a nos questionar sobre os seus direitos de ser e de viver. E são nestes processos de indagações sobre si mesmos e sobre as opressões vividas, que eles e elas vão construindo e escrevendo suas pedagogias libertadoras.

Ao se conscientizarem como sujeitos roubados de suas humanidades e como os únicos capazes de se resgatarem como gentes, os oprimidos e oprimidas começam a investir em projetos emancipadores. Nestes projetos, o educar-se, aprender-se sujeitos de direitos ganha um tom central em suas lutas. Como o próprio Paulo Freire já demarcou "a educação tem sentido porque o mundo não é necessariamente isto ou aquilo, porque os seres humanos são tão projetos quanto podem ter projetos no mundo" (FREIRE, 2016, p.44).

Assim, no sentido dos(as) oprimidos(as) e dos que com eles e elas lutam a "educação tem sentido porque mulheres e homens aprendem que é aprendendo que se fazem e refazem" (idem, ibidem). Ou seja, os esfarrapados do mundo se descobrem como "seres capazes de saber, de saber que sabem, de saber que não sabem" (idem). Neste processo de conscientização do mundo e do outro, viabiliza "a consciência de mim, inviabiliza a imutabilidade do mundo. A consciência do mundo e a consciência de mim me fazem um ser não apenas no mundo mas com o mundo e com os outros" (idem). Ou seja, no processo de se conhecer, de se saber sujeitos de direitos, tais oprimidos e oprimidas vão se notando como pessoas livres e emancipadas.

Quando se compreende a dança como uma prática educativa, nota-se a sua aproximação e seu compromisso com este processo de libertação. Inclusive, quando se pensa no ensino da dança, Joana Lopes (2008) destaca que tal ensino não se deva limitar ao que já foi construindo, mas que permita construir a dança no seu sentido formativo, no seu sentido de criação. E que os sujeitos aí envolvidos possam viver uma experiência de aprendizado com atitude, que leve à

criação da "nova cara da escola", como bem pensa Paulo Freire. Certamente sem incentivar uma maquiagem, mas pretendendo uma nova escultura, ágil e humana, que valorize a experiência na atitude de aprendizado para integrar conhecimentos. [...] Para tanto, como qualquer outra área, a repetição de técnicas substituindo a experiência como apoio formativo abre um abismo entre o pensar e o fazer. Não se trata de falar sobre e não fazer, mas de fazer e valorizar a palavra como expressão de emoções, 
pensamentos e decisões harmonizados com o movimento essencial do corpo. (p.8o)

Nesse sentido, pensar em dança como uma mera transmissão de passos prédefinidos pela(o) docente é pensar dança de forma extremamente limitada e seletiva. Esse método transmissivo, possui um caráter educativo bastante limitado, já que não permite a criatividade humana. A dança no seu sentido educativo libertador vai em sentido contrário a esta dimensão transmissiva. Pensada como prática emancipadora, a dança deve oferecer espaço para o desenvolvimento expressivo, criativo e que permita aos sujeitos envolvidos desvelar o que pensam e o que sentem através do movimento. Nesse diálogo, encontramos um ponto importante da dança no seu sentido educativo freireano, a saber: a dança como prática emancipadora, que envolve o corpo no ato de liberdade e de acolhimento do humano que ali se faz presente. Acolhido, o corpo que dança se sente capaz de se conhecer e se manifestar mais livremente. Isto só é possível, quando a dança se coloca como uma aprendizagem sensível, que envolve corpos conscientes de si e dos outros.

Portanto, compreender a dança no seu sentido emancipador é notá-la como práxis política. Freireanamente falando, a emancipação humana é sempre uma conquista política efetivada via práxis humana. Nela se encontra uma luta ininterrupta a favor da libertação das pessoas mediante qualquer forma de opressão e/ou dominação existes no mundo. Como práxis política, a dança é um movimento que busca levar o sujeito que dança a testemunhar o seu respeito à dignidade humana, manifestando assim, via corpos em movimento, relações de liberdade, de justiça, de conscientização do ser do estar sendo no mundo. Assim, o corpo que dança é sempre um corpo molhado de cultura.

\section{Dança - corpo molhado de cultura}

No livro Cartas a Guiné Bissau, Paulo Freire (2011) compartilha com seus leitores, que a primeira vez que ele pisou o chão da África, no percurso do aeroporto de Dar es Slaam à universidade, ele observava que o corpo dos africanos, eram corpos que gingavam, que sorriam e estavam a bailar pelas ruas. E este fazer e ser dos corpos africanos lhe traziam memórias:

[...] a mínimas coisas - velhas conhecidas - que começaram a falar a mim, de mim. A cor do céu, o verde-azul do mar, os coqueiros, as mangueiras, os cajueiros, o perfume de suas flores, o cheiro da terra, as bananas, entre elas a minha bem amada banana maça, o peixe ao leite de coco, os gafanhotos pulando na grama rasteira, o gingar do corpo das gentes andando nas ruas, seu sorriso disponível à vida, os tambores soando no fundo das noites, os corpos bailando e, ao fazê-lo, "desenhando o mundo". (FREIRE, 2011, p.14)

Nesse sentido, ao falarmos do corpo que dança não estamos destacando somente a dimensão do corpo sensível com os seus sentimentos e percepções de mundo, mas também de um corpo que carrega histórias e experiências, o corpo biográfico (JOSSO, 2012). Nessa perspectiva, revisitar nossas histórias por meio da dança, é também uma forma de tomar consciência do que somos hoje e nos emanciparmos. Para Josso (2012), a manifestação do corpo biográfico, inicia-se: 
por reconstruir o itinerário e os diferentes cruzamentos com os caminhos de outrem, as paragens mais ou menos longas no decurso do caminho, os encontros, os acontecimentos, as explorações e as atividades que permitem ao viajante não apenas localizar-se no espaço-tempo do aqui e agora, mas, ainda, compreender o que orientou, fazer o inventário da sua bagagem, recordar os seus sonhos, cortar as cicatrizes dos incidentes de percurso, descrever as suas atitudes interiores e os seus comportamentos (p. 21).

O corpo biográfico, nos permite articular o presente ao passado e ao futuro (JOSSO, 2012) proporcionando, inclusive, uma reflexão crítica sobre o que vivemos, do que pode ser reconstruído ou desconstruído, estimulando novos conhecimentos. E, ao biografar-se, são reveladas as marcas culturais que existem no corpo e na sua história.

Para Isabel Marques (2011), o que deve caracterizar o corpo que dança é a sua relação no e com o mundo. Entretanto, um corpo que não sente, não percebe e não se critica se torna um "corpo concha", limitado e impossibilitado de construir, criar e transformar. A dança, portanto, precisa estimular a conexão daqueles que dançam, entre eles e elas, com a sociedade, com suas histórias e com as diferentes realidades para assim produzir emancipações. Nesse sentido, Marques aborda a ideia de corpo social como sendo aquele que sofre influências externas, o tempo todo, e que guarda dentro de si questões familiares, de crenças, de religiões e de grupos os quais pertence. Assim, ela enfatiza a necessidade de olharmos para os corpos como corpos sociais e que, os corpos que dançam não expressam apenas movimentos. Eles "são pensamentos, percepções, atitudes, ideias, comportamentos e posicionamentos em constante diálogo com a arte e com o mundo" (MARQUES, 2011, p. 32).

Podemos, assim, considerar que, por meio do corpo que dança, é possível conhecer e refletir sobre diversos problemas e acontecimentos existentes na história e na sociedade e, por isso, parafraseando Chimamanda Ngozi Adichie (2019), as danças "podem também serem usadas para empoderar e humanizar" (p.32). Para Paulo Freire, o empoderamento é um processo interativo do ser humano com o mundo. Para ele, somos construídos como seres humanos, à medida que, criticamente, problematizamos a realidade e dela vamos tomando consciência de um bem-querer coletivo, capaz de descobrir brechas nas ideologias opressoras. Por isto para Freire, o corpo como cultura é o "corpo molhado de história, de marcas culturais, de lembranças, de sentimentos, de dúvidas, de sonhos rasgados, mas não desfeitos, de saudades de meu mundo, de meu céu das águas normas do Atlântico, da língua errada do povo, língua certa do povo" $(2018,17)$.

Quando dançamos, é este corpo história que se coloca em movimento. Como diz Freire (1991, p.51) "não posso pensar sem ser, nem ser sem meu corpo" e aqui tal pensamento se encontra com a dança-corpo cultural, social e biográfico. Ao dançar nossos corpos movem-se, agem-se e produzem situações de libertação. E este é o seu sentido freireano do corpo molhado de cultura: "o corpo move-se, age, rememora a luta de sua libertação, o corpo afinal deseja, aponta, anuncia, protesta, se curva, se ergue, desenha e refaz o mundo" (FREIRE, 1991, p.92). Portanto, o corpo que dança, coloca-se em comunicação pois está a projetar-se como "corpo-consciente" (idem), como nota-se a seguir. 


\section{Dança - comunicação}

A dança no seu sentido comunicativo não pode se limitar a movimentos repetitivos. Isso ignora a cultura, os costumes e as crenças dos corpos que dançam, sendo que esses aspectos não devem ser ignorados, como diria Paulo Freire (1983). No percurso dos corpos que dançam, existem percepções que estão sendo compartilhadas, recebidas e repensadas. Assim, enquanto uma experiência comunicativa, a dança é um espaço de troca de saberes, que podem despertar a curiosidade dos que dançam ou daqueles e daquelas que de alguma forma serão atravessados por aquela prática dançante. Ou seja, a dança - comunicação permite que os sujeitos envolvidos possam se comunicar entre si mesmos, com os outros e com o mundo.

O diálogo corporal, em todo o seu sentido amplo de possibilidades e sendo a comunicação viva, deve permitir um espaço em que as pessoas envolvidas não devam se envergonhar pelo que não sabem, mas sim, despertar o entusiasmo em dizer o que conhecem e a curiosidade em aprender o novo (FREIRE, 2018). Pensar a dança, neste sentido freireano da educação comunicativa, nos permite compreender a imensidão dos significados e percepções sobre o corpo que dança e suas vinculações com o mundo. O comunicar é sempre uma experiência de vinculação, ao comunicarse como corpo, o ser humano conscientiza-se do seu corpo como linguagem. Portanto, a dança é uma possibilidade de comunicação, ela é capaz de oferecer diálogos entre corpos diversos, deles com o mundo, deles com eles mesmos. Pois a comunicação como diria Paulo Freire é

[...] diálogo, assim como o diálogo é comunicativo. Em relação dialógicacomunicativa, os sujeitos interlocutores se expressam, como já vimos, através de um mesmo sistema de signos linguísticos. É então indispensável como ato comunicativo, para que este seja eficiente, o acordo entre os sujeitos, reciprocamente comunicantes. Isso é, a expressão verbal do sujeito tem que ser percebida dentro de um quadro significativo comum ao outro sujeito. Se não há este acordo em torno dos signos como expressões do objeto significado, não pode haver compreensão entre os sujeitos, o que impossibilita a comunicação. (p. 45-46)

Dessa forma, como prática comunicativa, a dança é uma experiência relacional dos corpos com suas culturas, dos corpos com os seus contextos. Em comunicação, o corpo é interação, é um projeto dialético do fazer-se humano. Pois, ao comunicar-se com o mundo, o corpo que dança não é adaptação ao mundo, ele é um projeto de sociedade. Paulo Freire (1983) nos mostra a importância do conhecimento como relação e não como extensão. Para ele o conhecimento "se constituí nas relações homem-mundo, relações de transformação e se aperfeiçoa na problematização crítica dessas relações" (FREIRE, 1983, p. 22).

Como processo de existência, o corpo em dança é um percurso que comunica as andarilhagens de homens e mulheres que se colocam em uma busca incansável rumo à vocação humana pelo Ser mais. Segundo Paulo Freire, o Ser mais é o princípio básico da ontologia humana, a saber: o ser humano nasceu para crescer, para emancipar-se, para caminhar e para dançar. Porém nossa caminhada rumo ao ser mais não é uma rota linear, passiva, matemática, informacional, transmissiva. Ao 
contrário, o existir humano é sempre uma experiência comunicativa dialógica, uma experiência vinculativa do ser humano no e com o mundo, portanto, uma atitude dialética e interacional. O que acontece, segundo Paulo Freire, é que nesta busca homens e mulheres em suas andarilhagens podem viver experiências de desencontros com a vocação do ser mais e viver ou sofrer situações de desumanização, de morte, de violação do direito de crescer.

Assim, neste desencontro dialético entre ser mais e ser menos, a dança tem sido um lugar político de denúncias das várias situações de desumanizações. Os dançarinos negros no Brasil, por exemplo, têm sido incansáveis nesta luta pela existência do corpo negro. Eles trazem para suas experiências do dançar, a relação dos corpos com suas ancestralidades; dos corpos com suas performances antirracistas; dos corpos com seus rituais afro-brasileiros. Estas relações nos é apresenta por Rosa(2015) em sua dissertação de mestrado, intitulada: A Suça em Natividade: festa, batuque e ancestralidade. Nela, Rosa nos informa como na performance da ancestralidade, tradição e memória são desenhadas no espaçotempo ritual através de uma dramaturgia do corpo. Tal autor destaca que a ancestralidade, seja de matriz banto ou ioruba, entre outras formas, anuncia-se o som do tambor e se inscreve nos corpos que respondem a ele. "O tambor toca o corpo e o corpo dança o tambor". (Rosa, 2015, p. 40)

Neste sentido, os(as) dançarinos(as) negros e negras tem feito da dança um lugar comunicativo, político e antirracista. O lugar de uma corporeidade viva ou que grita por justiça, como fazem os bailarinos Paulo Melgaço, Bethânia Gomes, Ingrid Silva e Ismael Silva. Este último, considerado a raiz negra da dança contemporânea. Em seus trabalhos com a dança, Ismael evoca o corpo movimento, contorcido em beleza e comunicação. Por isto, um corpo consciente de si e do mundo.

\section{Dança - conscientização}

Paulo Freire propõe a educação comunicativa como campo de possibilidades para o processo de conscientização que auxilie os seres humanos a uma postura crítico-histórica no mundo e transformadora da realidade. Quanto mais os indivíduos se tornem conscientes de uma realidade mais esta se "desvela" à sua frente. Ao se comprometerem com uma educação conscientizadora, homens e mulheres são capazes de refletir e agir sobre o mundo. E nesse processo educativo, tais sujeitos podem se reconhecer como agentes de mudanças. O comprometer-se com tais mudanças não se faz de forma passiva, mas implica consciência da realidade e, consequentemente, engajamento nos processos de lutas e transformações da vida humana. Assim diz Paulo Freire:

ao ouvir pela primeira vez a palavra conscientização, percebi imediatamente a profundidade de seu significado, porque estou absolutamente convencido de que a educação, como prática de liberdade, é um ato de conhecimento, uma aproximação crítica da realidade. (FREIRE, 1980b, p. 25)

Nesse sentido freireano, a conscientização "é um teste de realidade" (1980, p.26), ultrapassando, portanto, a ideia de apreensão espontânea do mundo. Quanto 
mais o sujeito se conscientizar no sentido de analisar e refletir sobre o que lhe é apresentado, mais coisas ele será capaz de (re)descobrir. Por esta razão

a conscientização não consiste em "estar frente a realidade" assumindo uma posição falsamente intelectual. A conscientização não pode existir fora da "práxis", ou melhor, sem o ato ação-reflexão. Esta unidade dialética constitui, de maneira permanente, o modo de ser ou de transformar o mundo que caracteriza os homens [...]. Por isso mesmo, a conscientização é um compromisso histórico. É também consciência histórica: é inserção crítica na história, implica que os homens assumam o papel de sujeitos que fazem e refazem o mundo. Exige que os homens criem sua existência com um material que a vida lhes oferece...(FREIRE, 1980, p.26).

Nesta perspectiva da conscientização, em 1960, segundo Jussara Miller (2013), iniciou-se um movimento contraposto às técnicas mais tradicionais em dança com a atenção voltada às práticas corporais que considerassem a sensibilidade, percepção e expressão corporal:

A tônica se voltava para a capacidade de comunicação. Em algumas pesquisas na área da dança, o movimento passou a ser trabalhado com um maior enfoque na percepção e na consciência, valorizando as sensações, intenções e o conhecimento do funcionamento do corpo, em lugar da forma e dos passos de dança [...]. No Brasil, Klauss e Angel Vianna tiveram papel pioneiro na pesquisa do movimento com enfoque somático [...] uma pesquisa de expressão e consciência corporal [...]. A expressão "consciência corporal” enfatiza a compreensão de que, na arte, vivenciamos e reconhecemos que o corpo está incluído nos processos da memória, de que os movimentos acionam e são acionados pelos sentidos, de que a consciência não está parada, mas presente no movimento corporal. (MILHER, 2013, p. 1-3)

Nesta dimensão da consciência corporal, temos uma conexão da técnica Klauss Vianna (2005) com os pensamentos de Paulo Freire sobre priorizar a conscientização no ato de ensinar. Para Vianna, as aulas de danças precisam considerar a realidade e possibilidade, que os corpos carregam, de se conectarem com o mundo. Portanto, o ensino da dança deve ter um compromisso de levar o corpo ao conhecimento de si, dos seus limites e das suas capacidades para que, a partir disso, ele possa se transformar:

Assim como o andar, os movimentos de agachar, sentar, deitar, levantar, também possibilitam observar o desempenho das articulações nas atitudes de posturas mais comuns, ou ainda as dificuldades na passagem de um movimento para o outro. É muito importante executar um movimento e perceber esses movimentos, pois eles acontecem a todo momento, quando sentamos numa cadeira, deitamos numa cama ou caminhamos pela rua. $\mathrm{E}$ para mim, mais do que numa aula, é no cotidiano que essa experiência de observação e questionamento deve ser vivenciada, permitindo que gestos comuns se convertam em atitudes mais ou menos conscientes. [...] sem que haja consciência desses movimentos e da maneira como continuamos fazêlo é muito difícil avançar em direção a movimentos mais elaborados, que já exigem um certo conhecimento e domínio de si mesmo. Se não levarmos 
em conta essa realidade, qualquer tentativa nesse sentido tende a fracassar ou a converter-se em pura ginástica. (VIANNA, 2005, p. 121)

Nessa perspectiva, para a construção de conhecimentos, preciso estar aberto a revisitar e refletir sobre a minha realidade. Vianna (2005) destaca que, a ausência de um trabalho de consciência corporal faz com que a(o) aluna(o) se sinta incapaz diante de movimentos preestabelecidos e conduzidos pelo outro. É justamente o que pode ocorrer nas escolas por meio de uma percepção, às vezes, equivocada, a respeito do ensino de dança, gerando um desinteresse por parte da(o) discente. Portanto, o conhecer-se é substituído pelas repetições de movimentos, desconsiderando as diferenças dos corpos. Assim, o autor nos revela que o caminho do ensino de dança deveria fazer com que gestos mecânicos e repetitivos se transformassem em movimentos conscientes e, por isso, reais:

A essência do trabalho corporal que proponho é a busca da sintonia e da harmonia com nosso próprio corpo, o que possibilita chegar a elaboração de uma dança singular, original, diferenciada e, por isso mesmo, rica em movimento e expressão. Para ser intérprete de minhas emoções tenho necessariamente de me despojar de uma imagem que me foi de alguma forma imposta para adotar a postura que corresponde à minha trajetória pessoal e à minha existência cotidiana. É o mesmo que apagar um quadro cheio de frases um novo analfabeto, de uma linguagem capaz de traduzir aquilo que verdadeiramente sinto e quero expressar. (p. 125-124)

Conscientizar-se, então, é um percurso constante em busca do conhecimento de si para compreender o que nos envolve, o que somos, do que somos capazes. $\mathrm{Na}$ dança preciso conhecer o meu corpo, a minha história, as minhas possibilidades, os meus movimentos corporais cotidianos para que seja possível uma transformação. Sem conhecermos, a priori, a nossa realidade, não há um caminho para mudanças. Está aí a importância em desenvolver a consciência corporal dos educandos para que possam se conectar com as práticas corporais, se sentirem incluídos e capazes de criar e ampliar movimentos dançantes e neles se reconhecerem como sujeitos de direitos.

\section{Conclusão}

Nos encontros da dança com educação libertadora de Paulo Freire, percebese a necessidade de interpretar o corpo como comunicação, que molhado de culturas, faz-se uma experiência de educabilidade do ser humano. O corpo que dança é movimento, é criação e conscientização. Portanto, a dança faz parte da ontológica vocação humana do ser mais. Quando possibilitamos o corpo ser mais, como já dizia Freire, ampliamos os sentidos das corporeidades humanas e de suas atuações ou ações no mundo.

Nesse sentido, a dança pode ser uma fonte fecunda para se pensar projetos de uma sociedade brasileira mais livre, diversa e humana. É nesta dimensão da liberdade, que o ensino da dança se encontra com a educação humanizadora freireana, aquela que está a "serviço da boniteza da presença humana no mundo, a 
serviço da seriedade da rigorosidade ética, da justiça, da firmeza do caráter, do respeito às diferenças, engajada na luta pela realização do sonho da solidariedade" (FREIRE, 2016, p.37-38).

Por fim, a dança como um fazer humano é sempre uma experiência de inacabamento. Ao longo de sua história, ela foi se refazendo como prática educativa e como comunicação humana. No seu refazer, ela significou também desconstruir relações opressoras, mecânicas e silenciadora das pluralidades dos corpos que dançam.

É nesta perspectiva libertadora, que a dança ao longo de sua historicidade foi se colocando como uma prática capaz de educar corpos conscientes de si e dos outros, corpos pensamentos, corpos emancipados, corpos políticos e esperançosos. E são nas produções destas corporeidades que a dança, enquanto uma ação humana, encontra-se com a perspectiva da educação libertadora de Paulo Freire. E nesse sentido, a dança se concretiza como parte da história, da necessidade existencial do ser humano. Ao longo de gerações, ela tem sido lócus de lutas pela expressão das diversidades, das diferenças, dos anseios, das vontades, das subjetividades, das coletividades e das sensibilidades humanas. Ela se torna um campo importante na formação do der humano, uma formação de corpos conscientes de si e do mundo. E, portanto, humanizados.

\section{REFERÊNCIAS}

ADICHIE, Chimamanda Ngozi. O perigo de uma história única. São Paulo: companhia das letras, 2019.

ARROYO, Miguel G. Ofício de mestre: imagens e autoimagens. 15. ed. Petrópolis, RJ: Vozes, 2013.

BARRETO, Débora. Dança: ensino, sentidos e possibilidades na escola. Campinas, SP: Autores Associados, 2004. p. 127.

CAMAZZOLA, Juliana M. Epistemologias do corpo: o encontro entre dança contemporânea e educação. [Dissertação] Universidade de Caxias do Sul, 2017. Disponível em: <http://catalogodeteses.capes.gov.br/catalogo-teses/\#!/>. Acesso em: 15 de nov. 2020.

DEWEY, John. Arte como experiência. São Paulo, Martins Fontes, 2010.

FREIRE, Paulo. Pedagogia dos sonhos possíveis. $3^{\text {a }}$ ed. Rio de Janeiro/São Paulo. Paz e terra, 2020.

. Pedagogia da Autonomia: saberes necessários à prática

pedagógica. 57. ed. São Paulo: Paz e Terra, 2018. 
. Pedagogia da Indignação. Cartas pedagógicas e outros

escritos. 3. Ed. São Paulo: Paz e Terra, 2016.

. Cartas à Guiné-Bissau: registros de uma experiência em processo. 5.ed. São Paulo: Paz e Terra, 2011.

. Pedagogia da autonomia: saberes necessários à prática educativa. $31^{\text {a }}$ ed. São Paulo: Paz e Terra, 2005.

. Educação na Cidade. São Paulo, Cortez, 1991.

. Educação como prática da liberdade. 11 . ed. Rio de Janeiro: Paz e Terra, 1980a.

Conscientização: teoria e prática da libertação: uma introdução ao pensamento de Paulo Freire [tradução de Kátia de Mello e Silva; revisão técnica de Bendito Eliseu Leite Cintra]. 3 ed. São Paulo: Moraes, 1980b.

1987.

. Pedagogia do oprimido. 17. ed. Rio de Janeiro: Paz e Terra,

. Extensão ou comunicação [tradução de Rosisca Darcy ;

prefácio. S de Jacques Conchol]. 7.ed. Rio de Janeiro: Paz e Terra, 1983.

. Educação e mudança. 29. ed. Rio de Janeiro: Paz e Terra,

1979.

FROMM, E. O Coração do Homem: seu gênio para o bem e para o mal. $6^{\text {a }}$ Ed. Rio de Janeiro: Guanabara, 1981

GARIBA, Chames Maria Stalliviere; FRANZONI, Ana. Dança escolar: uma possibilidade na Educação Física. Revista Movimento, Porto Alegre, v.13, n. 2, 2007. Disponível em: <https://seer.ufrgs.br/Movimento/article/view/3553>. Acesso em: 20 Out. 2018.

GOMES, Gerson F.; BICHELS, Aline; OLIVEIRA, Valdomiro de; VAGETTI, Gislaine C. A dança e a cultura sob um "olhar" de Paulo Freire. In: CONGRESSO INTERNACIONAL PAULO FREIRE: O LEGADO GLOBAL, 2, 2018, Belo Horizonte, MG. Anais do II Congresso internacional Paulo Freire: o legado global, Belo Horizonte, v.1 2018. Disponível em: $<$ https://proceedings.science/freire-globalconference-2018/papers/a-danca-e- 
a-cultura-sob-um-\%E2\%80\%9Colhar\%E2\%80\%9D-de-paulo-freire >. Acesso em 6 de Mai. 2020.

GOMES, Tainã M. Educação pela dança no ensino básico de Goiás.

Dissertação(Programa de Pós Graduação em Educação) Universidade Metodista de Piracicaba, 2015. Disponível em: <http://catalogodeteses.capes.gov.br/catalogoteses/\#!/>. Acesso em: 15 de nov. 2020.

JOSSO, Marie - Christine. O corpo Biográfico: corpo falado e corpo que fala.

Revista educação e realidade. Porto Alegre, v. 37, n.1, p. 19 -31, jan./abr, 2012.

LARROSA, Jorge. Tremores: escritos sobre experiência [Tradução: Cristina Antunes e João Wanderley Geraldi]. 1ed. Belo Horizonte: Autêntica, 2020.

LOPES, Joana. Dançando na escola: reflexões com Paulo Freire. Revista Múltiplas Leituras, v.1, n. 2, p. 76-81, jul. / dez, 2008. Disponível em: <https://www.metodista.br/revistas/revistasims/index.php/ML/article/view/1628>. Acesso em: 20 jun. 2019.

MARQUES, Isabel. Revisitando a dança educativa moderna de Rudolf Laban. Sala preta, 2011, n 2, p.273-281. Disponível em: <http://www.revistas.usp.br/salapreta/article/view/57104/60092>. Acesso em: 20 Mai. 2020.

MENOTI, Joyce Cristina Claro. Os jovens e a dança nas aulas de Educação física: um desvelar das culturas juvenis. Dissertação (Mestrado em educação) Faculdade de Ciências e tecnologia da Universidade Estadual Paulista. Presidente Prudente, 2017. Disponível em:

$<$ https://repositorio.unesp.br/bitstream/handle/11449/150573/menoti jcc me p rud.pdf?sequence $=3>$. Acesso em 29 de Abr. 2020.

MILLER, Jussara. Técnica Klauss Vianna: consciência em movimento. Revista do LUME, n.3, 2013. Disponível em:

$<$ https://www.cocen.unicamp.br/revistadigital/index.php/lume/article/view/258 $>$. Acesso em 20 de Mai. 2020.

NOGUEIRA, Judith Cristina Gouveia. Do movimento ao verbo:

desenvolvimento cognitivo e ação corporal. São Paulo: Annablume, 2008.

PERETTA, Eden Silva. Presença e inacabamento: aproximações entre dança e o pensamento crítico de Paulo Freire. Urdimento - Revista de Estudos em Artes Cênicas, Florianópolis, v.3, n.36, 2019. Disponível 
em:<http://www.revistas.udesc.br/index.php/urdimento/article/view/15807>. Acesso em 7 de Mai. 2020.

ROSA, E. M. A Suça em Natividade: festa, batuque e ancestralidade. 2015. 122f. Dissertação [Mestrado em Performance Cultural]. Universidade Federal de Goiás, Goiânia, 2015.

SILVA, Edna C. Dança na educação básica: uma análise de produção de conhecimento à luz da teoria corpomídia. [Tese] Pontifícia Universidade Católica de São Paulo, 2018. Disponível em: <http://catalogodeteses.capes.gov.br/catalogoteses/\#!/>. Acesso em: 15 de nov. 2020.

VECCHI, Anna Maria Barros de. Sobre o autor. In: LABAN, Rudolf. Domínio do movimento. Edição organizada por Lisa Uilmann [traducão: Anna Maria Barros de Vecchi e Maria Silvia Mourão Netto; revisão tecnica: Anna Maria Barros de Vecchi] - São paulo: Summus, 1978, p.9.

VIANNA, Klauss; CARVALHO, Marco Antônio de. A Dança. 6. ed. São Paulo: Summus, 2005.

VIEIRA, Marcílio de Souza. História das ideias do ensino da dança na educação brasileira (Parte II). Anais IX Reunião Científica Abrace, v. 18, n.1, 2017. Disponível em:

$<$ https://www.publionline.iar.unicamp.br/index.php/abrace/article/view/969/125 o $>$. Acesso em 22 de Mai. 2020.

VIEIRA, Marcílio de Souza. História das ideias do ensino da dança na educação brasileira. 1 ed. Curitiba: Appris, 2019.

ZIRKOSKI, Jaime José. Ser mais. In. Dicionário Paulo Freire. Org. STRECK D. R; REDIN, E; ZIRKOSKI, J. 3.ed. Belo Horizonte: Autêntica 2016. P.369-370.

\section{Sobre os autores}

Camila Moura Cardilo. Graduada em Educação Física e Pedagogia. Possui Especialização em Dança e consciência corporal pela Universidade Estácio de Sá. Mestranda em Educação e Formação Humana pela UEMG. Educadora, atuou como professora de dança em escolas e projetos sociais; atualmente é professora da Educação Básica. Desenvolve suas pesquisas nas áreas de educação, dançaeducação, formação humana, arte-educação, corporeidade, escola e diversidades, experiências e memórias. ORCID https://orcid.org/0000-0001-9917-3750 E-mail:: camilacardilo@gmail.com 
Cirlene Cristina de Sousa. Graduada em História pela UFMG. Possui Especialização em Comunicação e Culturas pela PUC-SP. Mestre em Comunicação Social pela UFMG. Doutora em Educação pela UFMG. Professora do Programa de Pós-graduação (Mestrado em Educação) e da Graduação em Pedagogia da UEMG. É pesquisadora do Observatório da Juventude da UFMG. Desenvolve suas pesquisas nas áreas de educação, linguagens, cultura midiática e juventudes, ensino Médio e políticas educacionais juvenis, escola e diversidades, comunicação e educação, formação de professores e pesquisa em educação. ORCID https://orcid.org/o0ooo003-3086-8081 E-mail: cirlenesousa@yahoo.com.br

\section{Tramitação:}

Recebido em:17/07/2021

Aprovado em: 29/12/2021 